\title{
Textural and mineralogical maturities and provenance of sands from the Budhi Gandaki-Narayani Nadi, central Nepal
}

\author{
Sanjay Singh Maharjan and Naresh Kazi Tamrakar * \\ Central Department of Geology, Tribhuvan University, Kirtipur, Kathmandu
}

\begin{abstract}
The Budhi Gandaki-Narayani Nadi in the Central Nepal flows across fold-thrust belts of the Tethys Himalaya, Higher Himalaya, Lesser Himalaya, and the Sub-Himalaya, and is located in sub-tropical to humid sub-tropical climatic zone. Within the Higher Himalayas and the Lesser Himalayas, a high mountain and hilly region give way the long high-gradient, the Budhi Gandaki Nadi in the northern region. At the southern region within the Sub-Himalayas, having a wide Dun Valley, gives way the long low-gradient Narayani Nadi. Sands from Budhi Gandaki-Narayani Nadi were obtained and analysed for textural maturity and compositional maturity. The textural analyses consisted of determining roundness and sphericity of quartz grains for shape, and determining size of sand for matrix percent and various statistical measures including sorting. The analysis indicates that the textural maturity of the majority of sands lies in submature category though few textural inversions are also remarkable. Sands from upstream to downstream stretches of the main stem river show depositional processes by graded suspension in highly turbulent (saltation) current to fluvial tractive current, as confirmed from the C-M patterns.

The compositional variation includes quartz, feldspar, rock fragments, mica, etc. The quartz grain percent slightly increases from the mountains to the lower relief areas. The percent feldspar decreases rapidly whereas the percent rock fragment decreases gradually along the downstream transport of sediment. The Budhi Gandaki-Narayani Nadi sands range from sublitharenite to lithic arenite composition in QFL diagram, and are remarkably poorer in feldspar compared to rock fragment. Among the rock fragments, the high-grade metamorphic rock fragments are dominant in the upstream stretch of the main stem Narayani Nadi stretch while the sedimentary lithics are remarkable in the downstream stretch. The QFL plots also show that the studied sands belong to recycled orogeny provenance and agree with the current tectonic setting of the Himalayas. Mineralogically, the sands (MMI $=100 \%-203 \%$ ) are not as matured as the normal sands. MMI fluctuates along downstream distance due to mixing of sediments from the major tributaries at various places along the main stem river.
\end{abstract}

Key words: Fluvial sand, Sedimentary process, Graphic measures, Textural maturity, Mineralogical maturity

Received: 2 February 2020

Accepted: 5 October 2020

\section{INTRODUCTION}

The Gandaki Nadi is one of the main rivers of Nepal. The Budhi Gandaki-Narayani Nadi are the major tributaries of the Gandaki River. The Gandaki Nadi has a total catchment area of 46,300 sq. km, and the Gandaki basin contains three of the world's 14 mountains over 8,000 meters, i.e. Dhaulagiri, Manaslu and Annapurna I. Among them the Manaslu is the source of the Budhi Gandaki Nadi. The other main tributaries of the Gandaki River are Trishuli, Marshyangdi, Madi, Seti Gandaki, Kali Gandaki and the Rapati Nadis (Fig. 1). Nepal covers about $700 \mathrm{~km}$ long segment stretching NW-SE of the Central Himalaya which is tectonically active consisting of fragile geology. Hence from the North to the South across the Himalayas different morphotectonic zones can be recognized

${ }^{\star}$ Corresponding author

Email Address: nktam.555@gmail.com

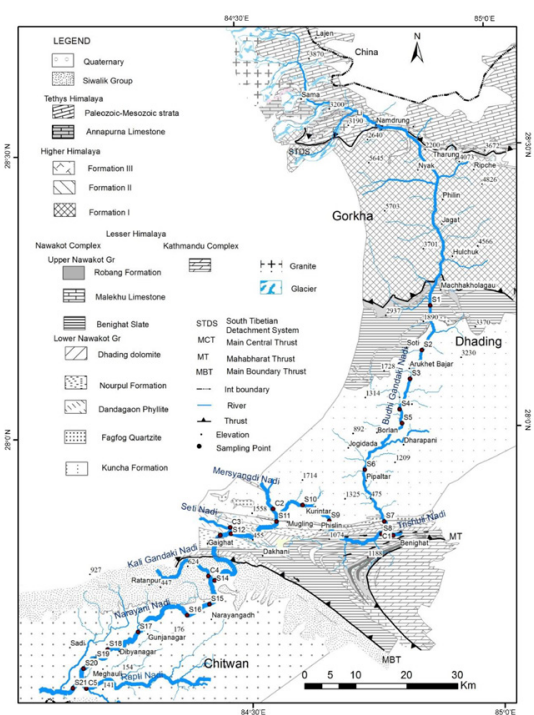

Fig. 1: Geological map of study area. Source complied from map of Central Nepal, Stöcklin and Bhattarai (1977), Geological Map of Central Nepal, DMG (1980), and Annapurna- Manaslu-Ganesh Himal, Colchen et al. (1986) 
(Kizaki, 1994). The Himalayan rivers are potential sources of detritus derived from eroding and denudating mountains.

Riverbank erosion and bank failure may produce a significant amount of sediment (Rosgen, 1976) in the Himalayan rivers. These sediments are deposited and transferred through the river systems and are finally carried to the Bay of Bengal through the grand river like the Ganges. The fluvial sediments are probably characterized by their composition and textural properties, which are believed to be not constant over the distance of transport along the river course, though they tended to be affected by frequent local contribution by contributories. The initial composition and texture of the sediment mainly depends on the source rock and tectonics (Ingersoll and Suczek, 1979; Dickinson et al., 1985). Depending upon the climate, topography and weathering conditions (Beryer and Bart, 1976), extent of abrasion and sorting and scale of recycling (Cavazza et al., 1993; Cox and Lowe, 1995), the sand composition and texture are affected.

The four major provenance terranes; stable craton, basement uplift, magmatic arc and recycled orogeny were distinguished in earlier studies (Ingersoll and Suczek, 1979; Dickinson et al., 1985). The detrital framework constituents of sand tend to vary depending on these provenance settings.

Buynevich and FitzGerald (2001) studied the textural and compositional characterization of recent sediments along a paraglacial estuarine coastline, Maine, USA. They analysed bottom sediments at the mouth of the Kennebec River and concluded that the mineralogical maturity increased from channel and outer bar to offshore sands.

Tamrakar and Gurmaita (2001) studied textural and compositional variation of sand along the Manahara-Bagmati River. They found that the grain size decreased downstream, sorting improved, quartz content increased whereas feldspar and rock fragments decreased downstream quite remarkably. The modified maturity index reported ranged from 19.8 to 214, which increased from the Manahara to Bagmati River sands.

Tamrakar and Shrestha (2008) suggested that rivers originating from the Lesser Himalaya with unstable slope are even more capable to flush out sediment compared to the rivers of the Siwaliks. Tamrakar et al. (2008) studied petrology of Rapati River sand, Hetauda-Chitwan Dun Basin, central Nepal and concluded that the Rapati River sand was quarto-lithic in composition and plotted on recycled orogeny provenance. The Rapati River sand was poorer in feldspar but richer in lithic fragments and quartz compared to the other sands/sandstones and also concluded that due to the dilution of feldspar by weathering and rapid breakdown in head waters the maturity of sand improved downstream.

Hulka and Heubeck (2010) studied composition and provenance history of late Cenozoic sediments in southeastern Boliva and concluded that the textural maturity of sandstone decreased stratigraphically upward throughout the section and mineralogical maturity decreased upsection of the Chaco Basin, probably due to the high degree of reworking in shoreline systems.

The aims of the present study were to assess the maturity status and their downstream variation for the fluvial sands from one of the major river systems of the Himalayan region, i.e., the Budhigandaki-Narayani Nadi stretch, and to verify the provenance mode for the studied sands.

\section{METHODOLOGY}

The sediment sample from the river was collected from intended location and exact location was marked and verified by looking topographic map and using GPS. The head water distance was taken from Samdo about $500 \mathrm{~m}$ south from the Larke Bazar from where the Budhi Gandaki Nadi begins to flow by melting of glaciers, e.g., Sonam Glacier. The Budhi Gandaki Nadi is the continuation of the Larke Khola.

For the purpose of compositional and textural studies, 25 sediment samples of about $500 \mathrm{~g}$ each were collected at interval of 10-15 km (Fig. 2), of which 20 sediment samples were from the Budhi Gandaki-Narayani Nadi and 5 samples were from the confluence rivers. They were obtained from bars, essentially above the flow level. Each sample was sieved at an interval of $1 \phi$. The sieve size was selected according to modified UddenWentworth grain-size scale proposed by Blair and McPherson (1990). The fraction retained in pan was further analysed using pipette analysis to obtain proportion of silt and clay in each sample.

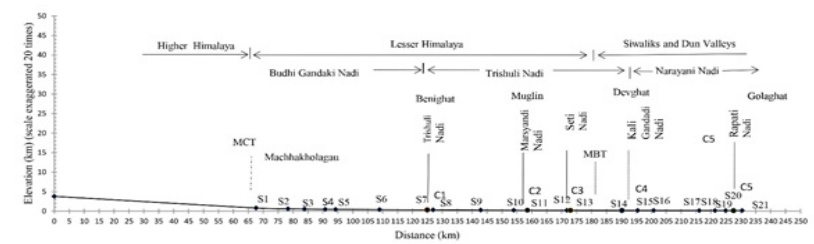

Fig. 2: Longitudinal profile of the Budhi Gandaki-Narayani Nadi

Graphic Mean (Mz), median (Md), Inclusive Graphic Standard Deviation (ÓI), Inclusive Graphic Skewness ( $\mathrm{SK}_{\mathrm{I}}$ ), and Graphic Kurtosis $(\mathrm{KG})$ were determined and interpreted according to the procedure of Folk and Ward (1957).

For the composition analysis, each of the three grain sized samples was cemented using epoxy. They were stained for feldspar and carbonate. For feldspar staining, the slide was stained in sodium cobaltinitrite solution and later Eosin 'B'. The potash feldspar stained to yellow and plagioclase stained to pink (Haye's and Klugman's method). In case of carbonate, the sand grain sample was stained in silver nitrate solution and potassium chromate. Carbonate grains stained a deep red brown. Then two-hundred grains per slide were point counted using modal analysis following Gazzi-Dickinson's method of counting. The constituents like quartz, feldspar, rock fragment, heavy mineral, mica and other grains were distinguished and counted and percentage was calculated.

For each of coarse, medium, fine and bulk sands, about 100 quartz grains were separated and studied for roundness and sphericity. Powers (1953) roundness chart was used to 
Textural and mineralogical maturities and provenance of sands from the Budhi Gandaki-Narayani Nadi.

Table 1: Summarized table of sample location, elevation distance from head water and description .

\begin{tabular}{|c|c|c|c|c|c|c|c|}
\hline S.N. & Sec & & Sam. & $\begin{array}{l}\text { Dist. } \\
(\mathrm{Km})\end{array}$ & Longitude/Latitude & Elev. (m) & Description \\
\hline 1 & \multirow{7}{*}{\multicolumn{2}{|c|}{ 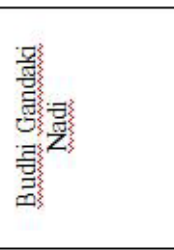 }} & S1 & 67.62 & $28^{\circ} 13^{\prime} 31.01^{\prime \prime} \mathrm{N} / 84^{\circ} 52^{\prime} 31.08^{\prime \prime} \mathrm{E}$ & 810 & Grey, sG, fresh, SB about $200 \mathrm{~m}$ long and $1 \mathrm{~m}$ thick \\
\hline 2 & & & $\mathrm{~S} 2$ & 78.28 & $28^{\circ} 08^{\prime} 14.88^{\prime \prime} \mathrm{N} / 84^{\circ} 51^{\prime} 22.61^{\prime \prime} \mathrm{E}$ & 611 & \multirow{2}{*}{$\begin{array}{l}\text { Grey, sG, fresh. SB about } 100 \mathrm{~m} \text { long and } 1 \mathrm{~m} \text { thick } \\
\text { Grey, sG, fresh. SB about } 200 \mathrm{~m} \text { long and } 0.5 \mathrm{~m} \text { thick }\end{array}$} \\
\hline 3 & & & S3 & 83.79 & $28^{\circ} 05^{\prime} 40.18^{\prime \prime} \mathrm{N} / 84^{\circ} 50^{\prime} 10.54^{\prime \prime} \mathrm{E}$ & 542 & \\
\hline 4 & & & S4 & 90.77 & $28^{\circ} 02^{\prime} 19.41^{\prime \prime} \mathrm{N} / 84^{\circ} 48^{\prime} 33.56^{\prime \prime} \mathrm{E}$ & 483 & D. gr., sG, fresh. SB about $300 \mathrm{~m}$ long and $1.5 \mathrm{~m}$ thick \\
\hline 5 & & & S5 & 94.24 & $28^{\circ} 00^{\prime} 39.01^{\prime \prime} \mathrm{N} / 84^{\circ} 48^{\prime} 44.72^{\prime \prime} \mathrm{E}$ & 459 & Grey, sG, fresh. SB about $200 \mathrm{~m}$ long and $0.5 \mathrm{~m}$ thick \\
\hline 6 & & & S6 & 108.95 & $27^{\circ} 55^{\prime} 49.38^{\prime \prime} \mathrm{N} / 84^{\circ} 44^{\prime} 09.80^{\prime \prime} \mathrm{E}$ & 390 & Grey, sG, fresh. SB about $100 \mathrm{~m}$ long and $1 \mathrm{~m}$ thick \\
\hline 7 & & & S7 & 124.95 & $27^{\circ} 48^{\prime} 57.90^{\prime \prime} \mathrm{N} / 84^{\circ} 46^{\prime} 52.90^{\prime \prime} \mathrm{E}$ & 343 & Y. gr., $\mathrm{pS}, \mathrm{sW}, \mathrm{SB}$ about $500 \mathrm{~m}$ long and $0.5 \mathrm{~m}$ thick \\
\hline 8 & \multirow{7}{*}{\multicolumn{2}{|c|}{ 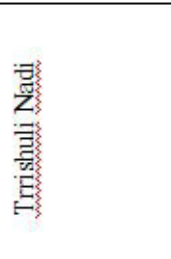 }} & S8 & 126.9 & $27^{\circ} 48^{\prime} 51.10^{\prime \prime} \mathrm{N} / 84^{\circ} 46^{\prime} 12.56^{\prime \prime} \mathrm{E}$ & 344 & Grey, sG, fresh. SB about $300 \mathrm{~m}$ long and $1 \mathrm{~m}$ thick \\
\hline 9 & & & S9 & 142.85 & $27^{\circ} 50^{\prime} 38.49^{\prime \prime} \mathrm{N} / 84^{\circ} 39^{\circ} 43.00^{\prime \prime} \mathrm{E}$ & 281 & Grey, sG, fresh. SB about $300 \mathrm{~m}$ long and $1 \mathrm{~m}$ thick \\
\hline 10 & & & S10 & 153.95 & $27^{\circ} 52^{\circ} 44.35^{\prime \prime} \mathrm{N} / 84^{\circ} 35^{\prime} 30.01^{\prime \prime} \mathrm{E}$ & 253 & Grey, sG, fresh. SB about $250 \mathrm{~m}$ long and $1 \mathrm{~m}$ thick \\
\hline 11 & & & S11 & 158.51 & $27^{\circ} 51^{\prime} 21.37^{\prime \prime} \mathrm{N} / 84^{\circ} 33^{\prime} 29.08^{\prime \prime} \mathrm{E}$ & 244 & Grey, sG, fresh. SB about $180 \mathrm{~m}$ long and $0.2 \mathrm{~m}$ thick \\
\hline 12 & & & S12 & 171.7 & $27^{\circ} 49^{\prime} 12.55^{\prime \prime} \mathrm{N} / 84^{\circ} 27^{\prime} 56.11^{\prime \prime} \mathrm{E}$ & 229 & L. gr., sG, fresh. SB about $300 \mathrm{~m}$ long and $1.5 \mathrm{~m}$ thick \\
\hline 13 & & & S13 & 172.93 & $27^{\circ} 49^{\prime} 15.23^{\prime \prime} \mathrm{N} / 84^{\circ} 27^{\prime} 17.47^{\prime \prime} \mathrm{E}$ & 218 & Grey, sG, fresh. MB about $150 \mathrm{~m}$ long and $1 \mathrm{~m}$ thick \\
\hline 14 & & & S14 & 190.18 & $27^{\circ} 44^{\prime} 29.93^{\prime \prime} \mathrm{N} / 84^{\circ} 25^{\prime} 35.70^{\prime \prime} \mathrm{E}$ & 194 & D. gr., $\mathrm{spS}$, fresh. SB about $500 \mathrm{~m}$ long and $1 \mathrm{~m}$ thick \\
\hline 15 & \multirow{7}{*}{ 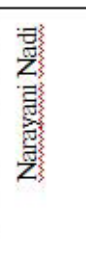 } & & S15 & 195.43 & $27^{\circ} 42^{\prime} 02.06^{\prime \prime} \mathrm{N} / 84^{\circ} 25^{\prime} 23.55^{\prime \prime} \mathrm{E}$ & 182 & D. gr., mS, d. gr., fresh. SB about $800 \mathrm{~m}$ long $/ 1 \mathrm{~m}$ thick \\
\hline 16 & & & S16 & 200.84 & $27^{\circ} 40^{\prime} 43.85^{\prime \prime} \mathrm{N} / 84^{\circ} 22^{\prime} 36.90^{\prime \prime} \mathrm{E}$ & 181 & D. gr., $c p S$, fresh. SB about $500 \mathrm{~m}$ long and $1 \mathrm{~m}$ thick \\
\hline 17 & & & S17 & 216.08 & $27^{\circ} 38^{\circ} 04.34^{\prime \prime} \mathrm{N} / 84^{\circ} 15^{\prime} 56.26^{\prime \prime} \mathrm{E}$ & 164 & D. gr., $\mathrm{cpS}$, fresh. SB about $9 \mathrm{~m}$ long and $0.2 \mathrm{~m}$ thick \\
\hline 18 & & & S18 & 221.38 & $27^{\circ} 36^{\circ} 45.61^{\prime \prime} \mathrm{N} / 84^{\circ} 13^{\prime} 15.39^{\prime \prime} \mathrm{E}$ & 158 & $\begin{array}{l}\text { D. gr., } \mathrm{cpS} \text {, fresh. SB about } 200 \mathrm{~m} \text { long and } 0.2 \mathrm{~m} \\
\text { thick }\end{array}$ \\
\hline 19 & & & S19 & 224.91 & $27^{\circ} 35^{\prime} 37.00^{\prime \prime} \mathrm{N} / 84^{\circ} 11^{\prime} 35.91^{\prime \prime} \mathrm{E}$ & 150 & D. gr., $\mathrm{spS}$, fresh. SB about $870 \mathrm{~m}$ long and $1 \mathrm{~m}$ thick \\
\hline 20 & & & $\mathrm{~S} 20$ & 227.57 & $27^{\circ} 34^{\prime} 42.28^{\prime \prime} \mathrm{N} / 84^{\circ} 10^{\prime} 23.24^{\prime \prime} \mathrm{E}$ & 146 & Y. gr., $\mathrm{cpS}, \mathrm{sW}, \mathrm{SB}$ about $800 \mathrm{~m}$ long and $1 \mathrm{~m}$ thick \\
\hline 21 & & & $\mathrm{~S} 21$ & 230.45 & $27^{\circ} 33^{\prime} 38.46^{\prime \prime} \mathrm{N} / 84^{\circ} 09^{\prime} 06.28^{\prime \prime} \mathrm{E}$ & 144 & D. gr., cps, fresh. SB about $900 \mathrm{~m}$ long and $1 \mathrm{~m}$ thick \\
\hline 22 & \multirow{5}{*}{ 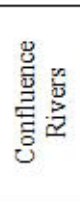 } & TN & $\mathrm{C} 1$ & $400 \mathrm{~m}$ & $27^{\circ} 48^{\prime} 50.13^{\prime \prime} \mathrm{N} / 84^{\circ} 47^{\prime} 05.35^{\prime \prime} \mathrm{E}$ & 336 & Y. gr., gS, sW, SB about $500 \mathrm{~m}$ long and $2 \mathrm{~m}$ thick \\
\hline 23 & & $\mathrm{MN}$ & $\mathrm{C} 2$ & $150 \mathrm{~m}$ & $27^{\circ} 51^{\prime} 32.19^{\prime \prime} \mathrm{N} / 84^{\circ} 33^{\prime} 30.44^{\prime \prime} \mathrm{E}$ & 249 & D. gr., sG, fresh. SB about $100 \mathrm{~m}$ long and $0.3 \mathrm{~m}$ thick \\
\hline 24 & & SN & $\mathrm{C} 3$ & $770 \mathrm{~m}$ & $27^{\circ} 49^{\prime} 28.85^{\prime \prime} \mathrm{N} / 84^{\circ} 27^{\prime} 37.93^{\prime \prime} \mathrm{E}$ & 226 & D. gr., gS, fresh. SB about $600 \mathrm{~m}$ long and $2.5 \mathrm{~m}$ thick \\
\hline 25 & & KGN & $\mathrm{C} 4$ & $400 \mathrm{~m}$ & $27^{\circ} 44^{\prime} 38.27^{\prime \prime} \mathrm{N} / 84^{\circ} 25^{\prime} 22.96^{\prime \prime} \mathrm{E}$ & 198 & Y. gr., spS, sW, SB about $150 \mathrm{~m}$ long and $0.5 \mathrm{~m}$ thick \\
\hline 26 & & $\mathrm{RN}$ & $\mathrm{C} 5$ & $1620 \mathrm{~m}$ & $27^{\circ} 33^{\prime} 32.32^{\prime \prime} \mathrm{N} / 84^{\circ} 10^{\prime} 05.24^{\prime \prime} \mathrm{E}$ & 142 & Y. gr., $\mathrm{spS}, \mathrm{sW}, \mathrm{SB}$ about $1000 \mathrm{~m}$ long and $0.5 \mathrm{~m}$ thick \\
\hline
\end{tabular}

Where, Sam. = sample number, dist. $=$ distance form head water, $\mathrm{d}$. $=$ dark, gr. $=$ grey; $\mathrm{sG}=$ sandy gravel, $\mathrm{pS}=$ pebbly sand, $\mathrm{cpS}=$ cobble pebble sand, $\mathrm{gS}=$ gravelly sand, $\mathrm{mS}=$ muddy sand; $\mathrm{SB}=$ side bar; $\mathrm{sW}$ = slightly weathered, $\mathrm{mW}=$ moderately weathered, $\mathrm{F}=$ fresh;

compare the outlines of quartz to determine roundness value of Folk (1955). For determining the projection sphericity, Rittenhouse's (1943) chart was used.

Sands were classified texturally ad compositionally. Textural maturity of sands was determined using criteria of Folk (1951). Folk (1951) studied stages of textural maturity in sedimentary rocks and concluded that there are mainly four stages of textural maturity in sediments, (i) immature, (ii) sub mature (iii) mature and (iv) super mature. Besides, Folk (1980) also suggested for textural inversion occurring in sediment.

Compositional maturity was determined from modified Maturity Index (MMI) of McBride and Picard (1987). Initially, Pettijohn (1957) introduced the mineralogical maturity index as:

$\mathrm{MI}=(\%$ quartz $+\%$ chert $) * 100 /(\%$ feldspar $+\%$ rock fragments $)$.

McBride and Picard (1987) and Picard and McBride (1993) have introduced modified maturity index as:

MMI $=(\%$ quartz $+\%$ chert $) * 100 / \%$ other grains.

They suggested that for mineralogical maturity the heavy minerals, mica and skeletal grains play important role.

\section{RESULTS}

\section{Classification of sand size grade}

The majority of the samples were fresh and are light grey to dark grey in colour (Table 1). Sediments from the Budhi Gandaki Nadi ranged from slightly muddy sand to sand (Table 2; Fig. 3). Those of the Trishuli Nadi and Narayani Nadi ranged from gravelly sand to sand. The samples from the confluence rivers were mainly sand.

Table 2: Sediment texture of samples

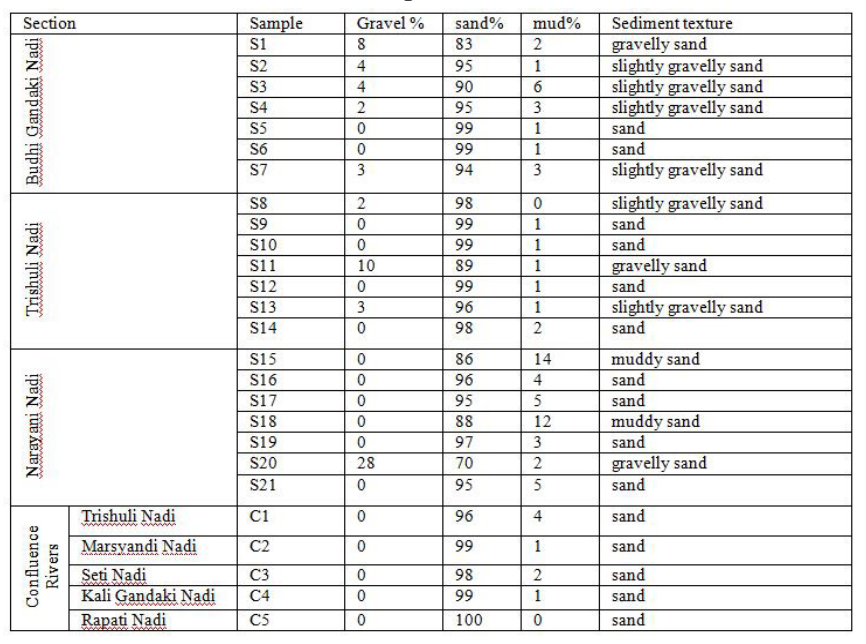




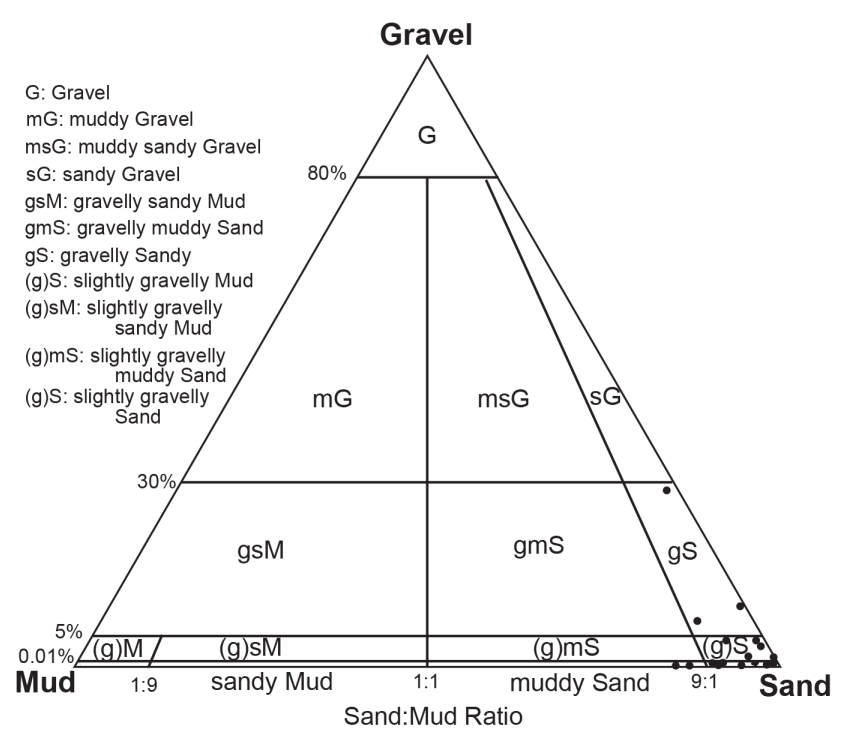

Fig. 3: Gravel, sand and mud triangular diagram (after Folk 1974) for classifications and nomenclature of the Budhi Gandaki-Narayani Nadi sediments.

\section{Statistical parameters of grain size}

In the Budhi Gandaki Nadi Segment, Mean (Mz) and median (\$50) grain sizes range, respectively from $1.45 \phi(\mathrm{S} 2)$ to $2.55 \phi(\mathrm{S} 3)$ and from $1.6 \phi(\mathrm{S} 2)$ to $2.6 \phi(\mathrm{S} 3)$ (Table 3). Inclusive graphic standard deviation of samples from the Budhi Gandaki Nadi Segment ranges from $0.47 \phi(\mathrm{S} 5)$ to $1.36 \phi(\mathrm{S} 2)$, and are poorly to moderately sorted. Inclusive Graphic Skewness (SKI) ranges from -0.09 (S1) to 0 (S5) as from coarse-skewed to near symmeritical skewness. Kurtosis (KG) ranges from $1.06(\mathrm{~S} 1)$ to $1.97(\mathrm{~S} 3)$, and are mesokurtic to very leptokurtic, respectively.

Mean $(\mathrm{Mz})$ and median $(\phi 50)$ grain sizes of samples from the Trishuli Nadi range from $1.36 \phi(\mathrm{S} 11)$ to $2.45 \phi(\mathrm{S} 14)$ and from $1.75 \phi(\mathrm{S} 8)$ to $2.5 \phi(\mathrm{S} 14)$, respectively. The samples are poorly $1.28 \phi(\mathrm{S} 12)$ to moderately $0.54 \phi(\mathrm{S} 9)$ sorted. Skewness (SKI) ranges from $-0.36(\mathrm{~S} 12)$ to $0.04(\mathrm{~S} 13)$ as from strongly coarse-skewed to near symmeritical skewness. Kurtosis (KG) ranges from 0.45 (very platykurtic, S12) to 1.20 (leptokurtic, S8).

Table 3: Summarized table of gran size parameters of sands from Budhi Gandaki-Narayani Nadi: (a) percentiles and (b) statistical measures

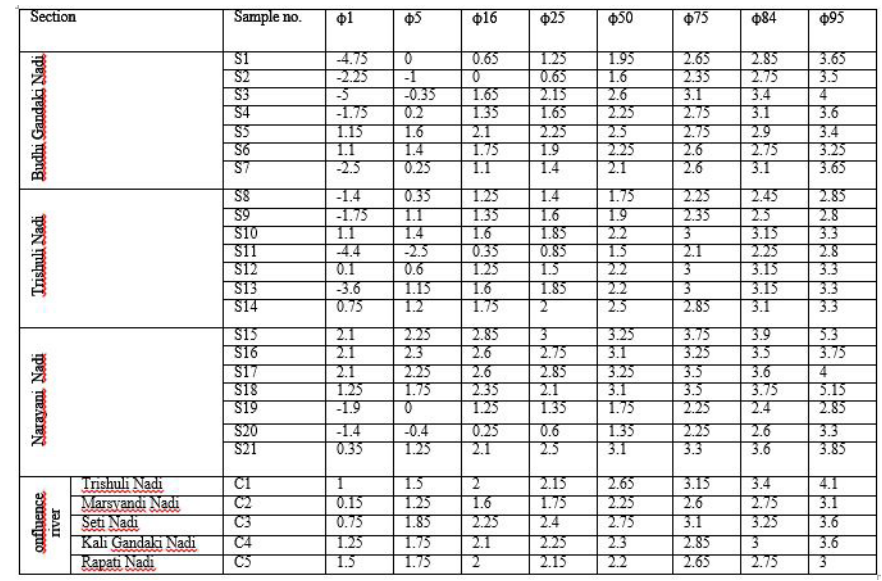

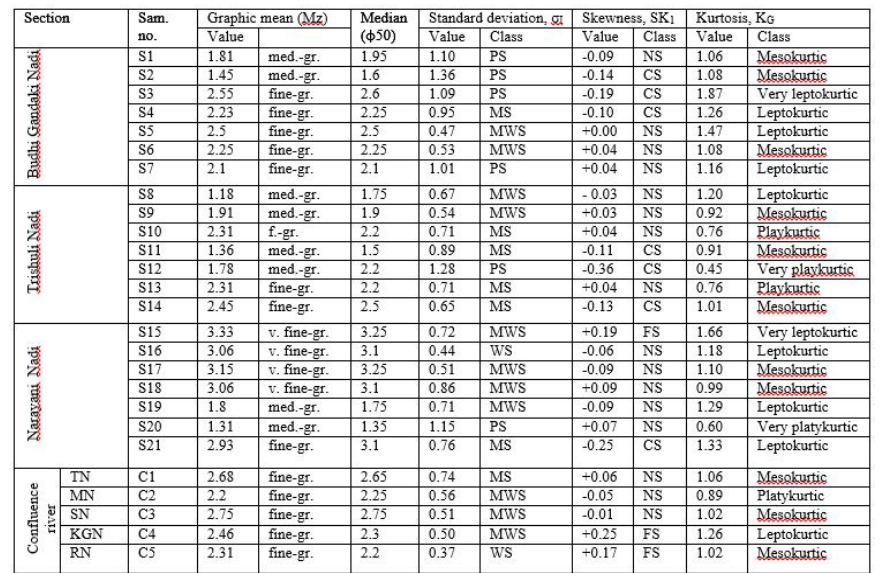

In the Narayani River Segment, Mean (Mz) and median ( $\$ 50)$ grain sizes range respectively from $1.8 \phi(\mathrm{S} 19)$ to $3.33 \phi(\mathrm{S} 15)$ and from $1.35 \phi(\mathrm{S} 20)$ to $3.25 \phi(\mathrm{S} 15$ and $\mathrm{S} 17)$. Inclusive graphic standard deviation of samples shows moderately sorted $0.44 \phi$ (S16) to poorly sorted $1.15 \phi$ (S20). Skewness (SKI) ranges from $-0.25(\mathrm{~S} 21)$ to $0.19(\mathrm{~S} 15)$ as from coarse-skewed to fine skewness. Kurtosis $(\mathrm{KG})$ ranges from 0.60 (very platykurtic, S20) to 1.33 (leptokurtic, S21) (Fig. 4; Table 3).

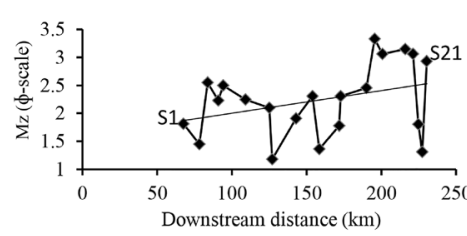

The confluence river sample (C1) from the Trishuli Nadi is moderately sorted, near symmetrical skewed and mesokurtic.

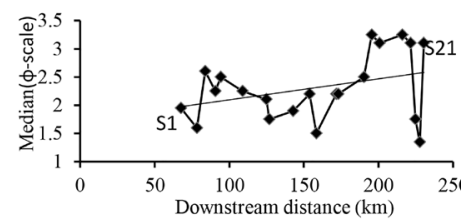
the Marsyangdi Nadi is moderately well sorted near symmetrical skewed and platykurtic (Table 6). The confluence river sample

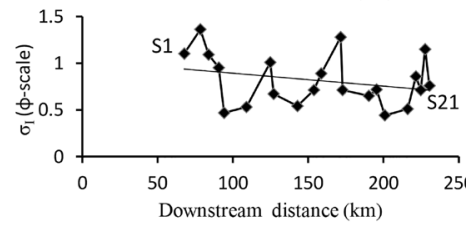
C3 from the Seti Nadi is moderately well sorted, near symmetrical skewed and mesokurtic, whereas the confluence river sample C4 from the Kali Gandaki

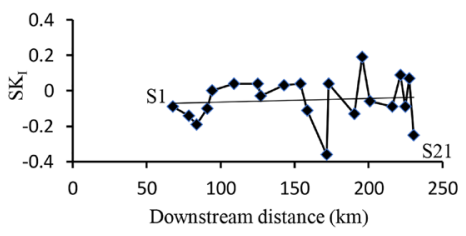
Nadi is moderately well sorted, finely skewed and mesorkurtic. The sample C5 from the Rapati Nadi shows well sorting, $50 \quad 100 \quad 150 \quad 200$
Downstream distance $(\mathrm{km})$ Fig. 4: Downstream variation trends which means the sorting of graphic measures improves from poor sorting to well sorting indicating that the sand sized sediments tend to be well sorted towards downstream (Fig. 4: Table 3). The improvement of sorting against the distance of transport is attributed to hydraulic sorting and contribution of fines form the confluence rivers and streams. The overall skewness fluctuates but a trend line 
slightly increases indicating the apparent increase of fines in the downstream stretches. Relatively coarse skewed sediments in the Budhi Gandaki Nadi compared to those from the Narayani Nadi Segment reflects higher gradient and stream power of the former river.

\section{Grain size plot on C-M diagram}

From C-M diagram plot (IV and V categories), the river dominated by sediments of graded suspension in highly turbulent current and river tractive current deposits (Table 4, Fig. 5). Most of the Budhi Gandaki and the Trishuli Nadi have transported sands in suspension, and the Narayani River has transported sands in bed load transport. It may be due to the gradient of the rivers. Therefore, plotting the sand samples shows that some river sand sized sediments have transported in graded suspension while others in tractive current (Fig. 5).

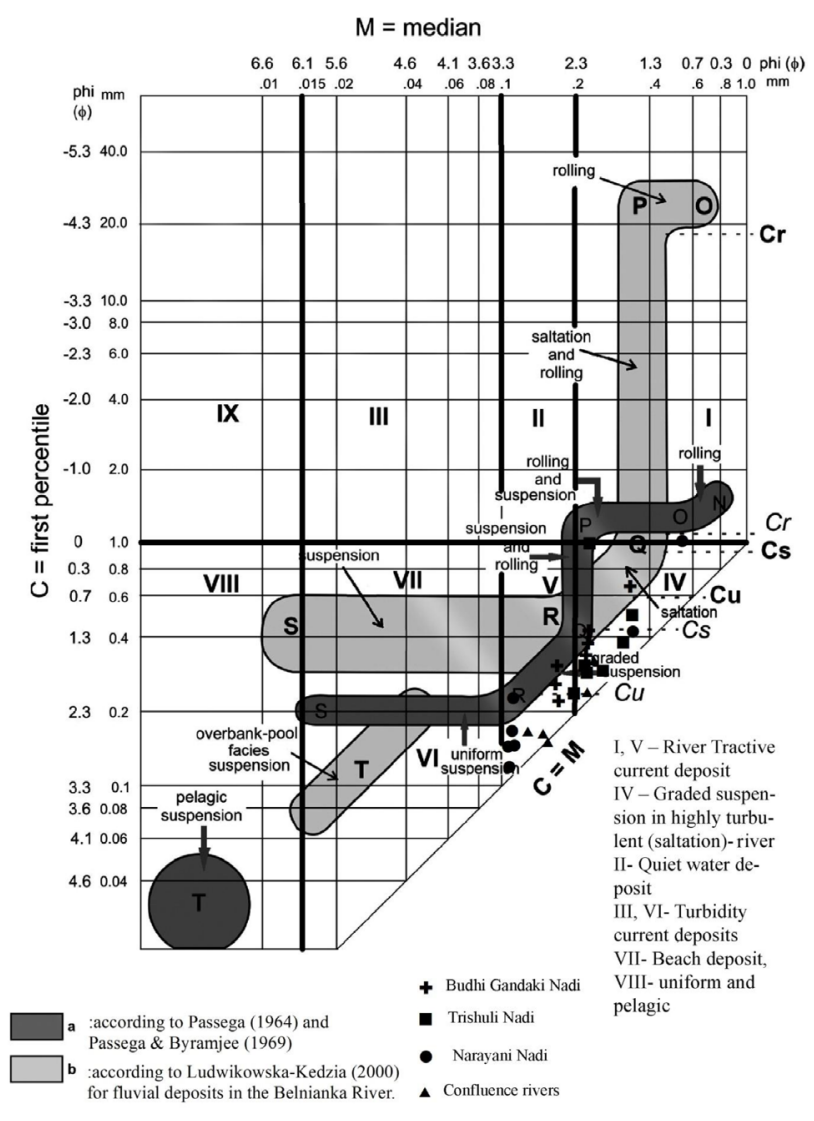

Fig. 5: Plot C-M diagram of the Budhi Gandaki-Narayani Nadi sediments

\section{Grain shape}

Quartz is the most widely studied grain type among the grains for the shape study due to its relative durability to chemical decomposition and mechanical breakdown (Pettijohn et al. 1987). Therefore, roundness and sphericity were estimated for the quartz grains. Roundness ranged from 1.56 to 2.86 for coarse sand fraction, 1.66 to 3.08 for medium sand fraction, 2.42 to 3.5 for fine sand fraction and 1.88 to 3.01 for bulk sand fraction (Table 5). Roundness indicates that the river
Table 4: Summarized table of C-M diagram

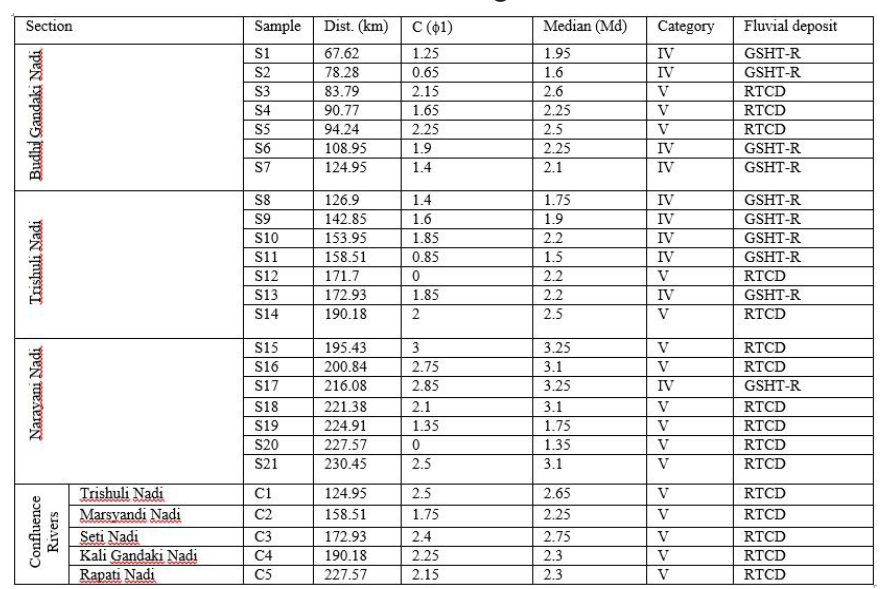

Where, GSHT-R = Graded suspension in highly turbulent (saltation)river, $\mathrm{RTCD}=$ River tractive current deposit, $\mathrm{Spl}=$ sample number, Dist. $(\mathrm{km})=$ distance in kilometer

is active in abrasion, however, due to the mixing of the sediments from other river, the roundness varies. Sphericity ranges from 0.68 to 0.76 for coarse sand, 0.67 to 0.74 for medium sand, 0.69 to 0.74 for fine sand and 0.69 to 0.72 for bulk sand. Sphericity of all coarse, medium, fine and bulk sands suggests that the sphericity of quartz grains varied less than roundness (Table 5). Roundness of quartz in all the size fractions of sands of the Budhi Gandaki-Narayani Nadi tends to increase as the distance of transport increases. The fine sand shows the better trends compared to other sand fractions (Fig. 6).

Table 5: Result of grain shape analysis of sand

\begin{tabular}{|c|c|c|c|c|c|c|c|c|c|c|c|c|}
\hline \multicolumn{2}{|c|}{ Section } & \multirow[t]{2}{*}{ SN } & \multirow[t]{2}{*}{ Dist. (Km) } & \multicolumn{5}{|c|}{ Mean roundness } & \multicolumn{4}{|c|}{ Mean Sphericity } \\
\hline & & & & CS & MS & FS & $\mathrm{BK}$ & Val & CS & MS & FS & $\mathrm{BK}$ \\
\hline \multirow{7}{*}{\multicolumn{2}{|c|}{ 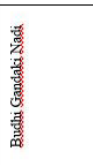 }} & S1 & 67.62 & 1.56 & 1.66 & 2.42 & 1.88 & A & .76 & .74 & .73 & 0.74 \\
\hline & & $\mathrm{S} 2$ & 78.28 & 2.06 & 2.04 & 2.74 & 2.28 & SA & .73 & .71 & .70 & 0.71 \\
\hline & & S3 & 83.79 & 1.82 & 2.5 & 2.85 & 2.39 & $\mathrm{SA}$ & .70 & .71 & .69 & 0.70 \\
\hline & & S4 & 90.77 & 1.98 & 2.16 & 2.94 & 2.36 & SA & .71 & .73 & .72 & 0.72 \\
\hline & & S5 & 94.24 & 1.75 & 2.32 & 2.74 & 2.27 & $\mathrm{SA}$ & .73 & .71 & .69 & 0.71 \\
\hline & & S6 & 108.95 & 2 & 2.66 & 2.72 & 2.46 & $\mathrm{SA}$ & .68 & .67 & .71 & 0.69 \\
\hline & & \$7 & 124.95 & 2.22 & 2.56 & 2.9 & 2.56 & SA & .74 & .74 & .71 & 0.73 \\
\hline \multirow{7}{*}{\multicolumn{2}{|c|}{ 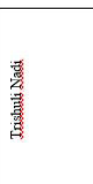 }} & ss & 126.9 & 2.84 & 2.64 & 2.92 & 2.80 & $\mathrm{SA}$ & .70 & .71 & .67 & 0.69 \\
\hline & & S9 & 142.85 & 2.82 & 2.98 & 3.3 & 3.03 & SR & .73 & .71 & .69 & 0.71 \\
\hline & & S10 & 153.95 & 2.68 & 2.81 & 2.82 & 2.77 & $\mathrm{SA}$ & .72 & .71 & .69 & 0.71 \\
\hline & & S11 & 158.51 & 2.71 & 2.78 & 3.1 & 2.86 & $\mathrm{SA}$ & .73 & .69 & .71 & 0.71 \\
\hline & & S12 & 171.7 & 2.38 & 2.6 & 2.98 & 2.65 & $\mathrm{SA}$ & .71 & .72 & .71 & 0.71 \\
\hline & & S13 & 172.93 & 2.66 & 2.56 & 3.28 & 2.83 & $\mathrm{SA}$ & .76 & .74 & .73 & 0.74 \\
\hline & & S14 & 190.18 & 2.92 & 3.06 & 3.18 & 3.05 & SR & .74 & .69 & .72 & 0.72 \\
\hline \multirow{7}{*}{\multicolumn{2}{|c|}{$\begin{array}{l}\text { 莈 } \\
\text { 喜 } \\
\text { 募 }\end{array}$}} & S15 & 195.43 & 2.62 & 2.84 & 3.5 & 2.99 & $\mathrm{SA}$ & .74 & .73 & .74 & 0.74 \\
\hline & & S16 & 200.84 & 2.75 & 2.84 & 3.04 & 2.88 & $\mathrm{SA}$ & .73 & .71 & .71 & 0.72 \\
\hline & & $\$ 17$ & 216.08 & 2.85 & 2.96 & 3.36 & 3.06 & $\mathrm{SR}$ & .74 & .73 & .69 & 0.72 \\
\hline & & S18 & 221.38 & 2.76 & 2.84 & 1.96 & 2.52 & SA & .73 & .71 & .72 & 0.72 \\
\hline & & $\$ 19$ & \begin{tabular}{|l|}
224.91 \\
\end{tabular} & 2.86 & 2.8 & 3.2 & 2.95 & SA & .74 & .73 & .71 & 0.73 \\
\hline & & $\$ 20$ & 227.57 & 2.74 & 2.26 & 3.14 & 2.71 & SA & .74 & .73 & 69 & 0.72 \\
\hline & & S21 & 230.45 & 2.78 & 3.08 & 1.96 & 2.61 & $\mathrm{SA}$ & - & .71 & .71 & 0.71 \\
\hline \multirow{5}{*}{ 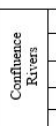 } & & $\mathrm{C} 1$ & 124.95 & 2.3 & 2.36 & 2.93 & 2.53 & $\mathrm{SA}$ & .74 & .74 & .71 & 0.73 \\
\hline & $\mathrm{MN}$ & $\mathrm{C} 2$ & 158.51 & 2.58 & 2.81 & 2.87 & 2.75 & $\mathrm{SA}$ & .73 & .71 & .67 & 0.70 \\
\hline & SN & C3 & 172.93 & 2.76 & 2.29 & 2.61 & 2.55 & $\mathrm{SA}$ & .70 & .71 & .72 & 0.71 \\
\hline & $\mathrm{KGN}$ & C4 & \begin{tabular}{|l}
190.18 \\
\end{tabular} & 2.92 & 3.54 & 3.18 & 3.21 & $\mathrm{SR}$ & .76 & .72 & .73 & 0.74 \\
\hline & $\mathrm{RN}$ & C5 & 227.57 & 3.16 & 2.84 & 2.88 & 2.96 & $\mathrm{SA}$ & \begin{tabular}{|l|}
.74 \\
\end{tabular} & .72 & .72 & 0.73 \\
\hline
\end{tabular}

Where, $\mathrm{CS}=$ coarse fraction sand, $\mathrm{MS}=$ medium fraction sand, $\mathrm{FS}=$ fine fraction sand and $\mathrm{BK}=$ bulk sand, Dist. = distance from head water, $\mathrm{TN}=$ Trishuli Nadi, $\mathrm{MN}=$ Marsyandi River, $\mathrm{SN}=$ Seti Nadi, KGN= Kali Gandaki Nadi and RN= Rapati Nadi. Val = value

The textural maturity of the Budhi Gandaki- Narayani Nadi is dominated by sub mature texture. The range of texture maturity varied from immature to mature but the sub mature is dominant, since it depends upon mud \%, roundness and sorting. The Budhi Gandaki-Narayani Nadi Segment lacks matured sediment due to presence of notable matrix. But in 
case of the Narayani Nadi, the samples S15 and S18 show textural abnormality perhaps due to the mixing of fines from mud flows. Mixing of the Kali Gandaki Nadi into the Trishuli Nadi adds fines causing textural abnormality (Fig. 7, Table 6) in the sediment.
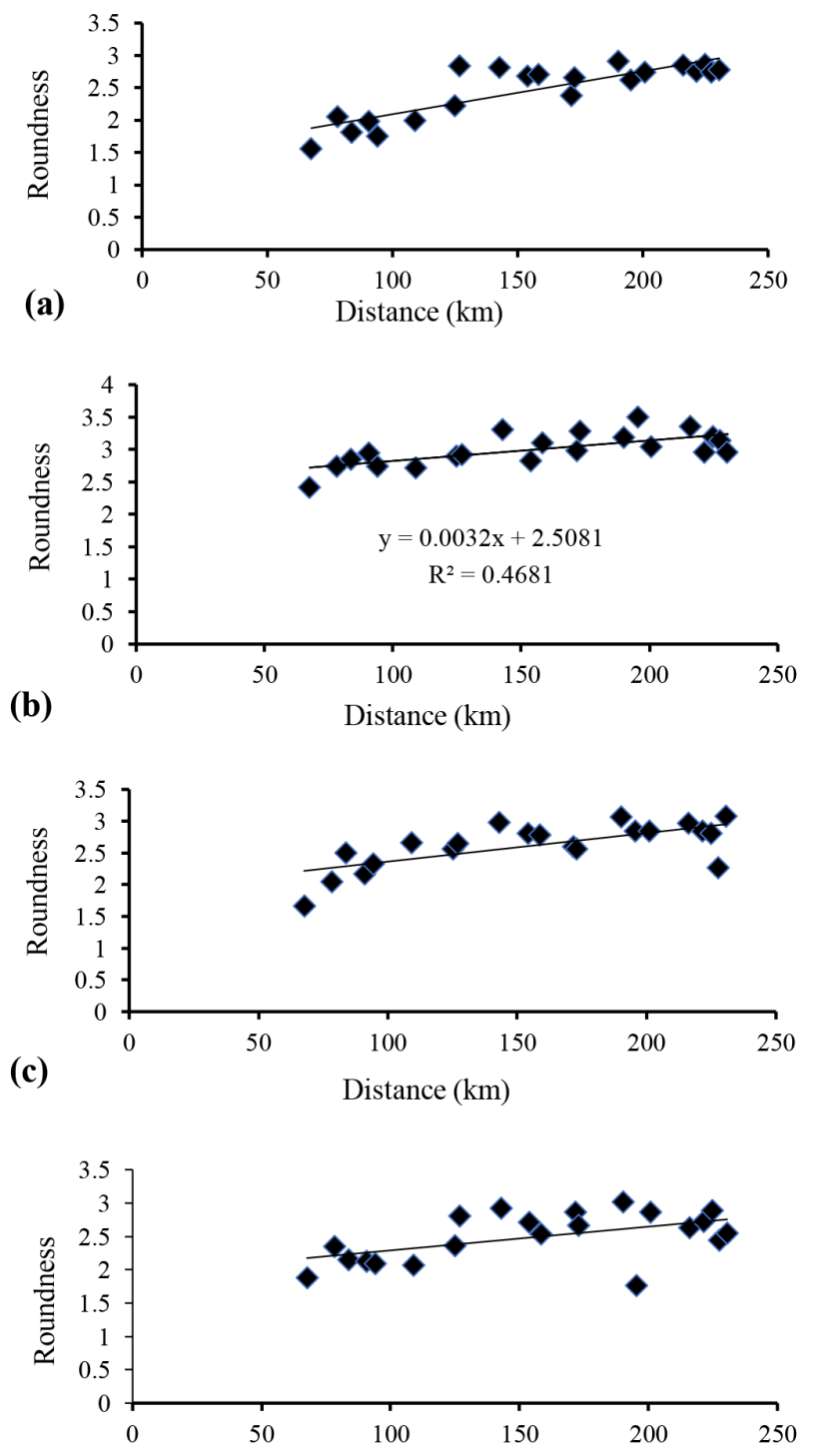

(d)

Distance (km)

Fig. 6: Roundness vs. distance of sand samples: (a) coarse fraction sand, (b) medium fraction sand, (c) fine fraction sand, and (d) bulk fraction of sand.

\section{Variation trends of sand composition Quartz}

In the Budhi Gandaki Nadi, quartz varies from 50\% (S1) to $67 \%$ (S7). The percentage of quartz decreases up to $110 \mathrm{~km}$ of the Budhi Gandaki Nadi, and begins to increase at $120 \mathrm{~km}$ at the Trishuli Nadi where quartz content varies from $58 \%$ (S10) to 64\% (S11), and the content increases up to $160 \mathrm{~km}$ downstream and then again it decreases up to $210 \mathrm{~km}$ in the Narayani Nadi Segment. The quartz percent in the Narayani Nadi varies from 53\% (S15) to 64\% (S21) (Table 7; Fig. 8a). Although the trend line of quartz percentage fluctuates, the overall trend shows that the quartz percent slightly increases towards downstream (Fig. 9a).
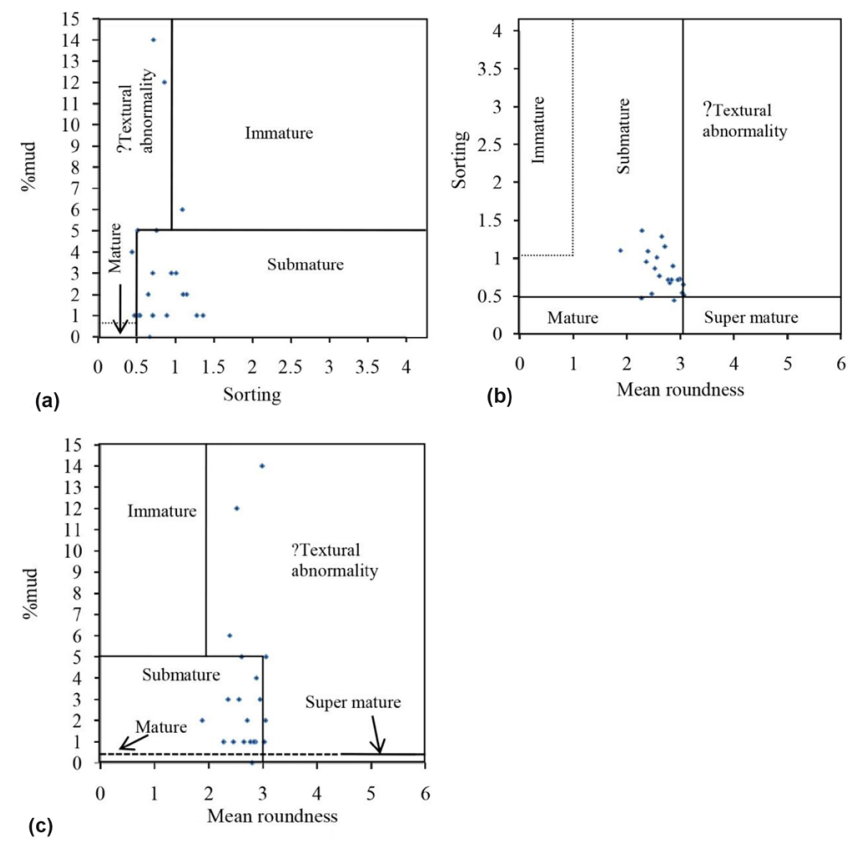

Fig. 7: Bivariate plot: (a) sorting versus \%mud, (b) mean roundness versus sorting, and (c) mean roundness versus \%mud showing most of the plots over the sub mature field. Solid boundaries (arbitrary boundaries) and dashed boundaries (not clearly defined) are based on Folk (1980) of the Budhi Gandaki-Narayani Nadi. (Diagram taken from Tamrakar and Gurmaita 2001)

Table 6: Summarized table of textural maturity

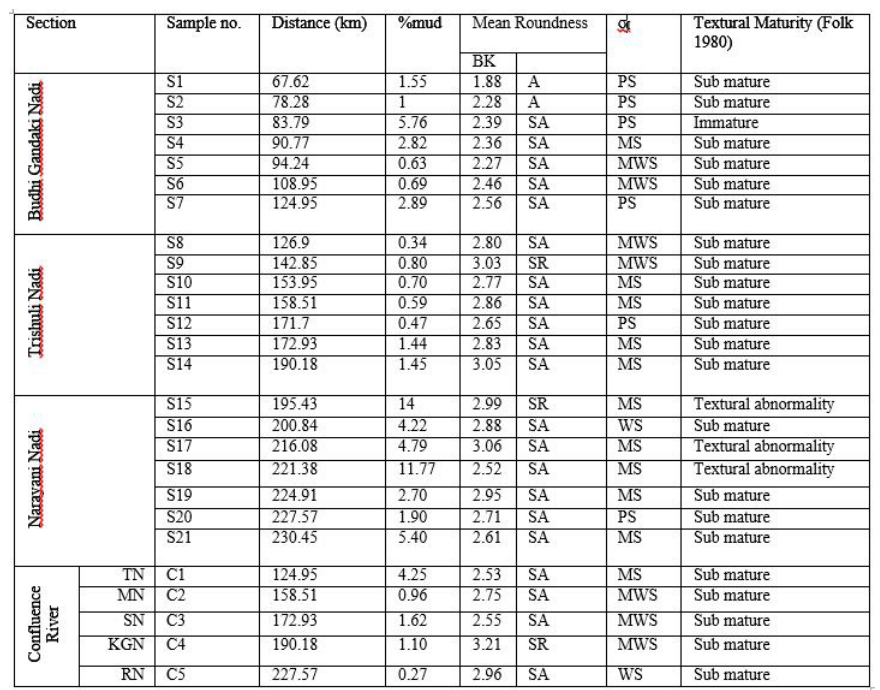

Where, $\mathrm{BK}=$ Bulk sand, $\mathrm{A}=$ angular, $\mathrm{SA}=\mathrm{Sub}$ angular, $\mathrm{SR}=\mathrm{Sub}$ rounded, $\mathrm{TN}=$ Trishuli Nadi, $\mathrm{MN}=$ Marsyandi Nadi, $\mathrm{SN}=$ Seti Nadi, $\mathrm{RN}=$ Rapati Nadi. $\mathrm{Spl}=$ sample number. $\mathrm{PS}=$ Poorly sorted, $\mathrm{MS}=$ Moderately Sorted, MWS $=$ Moderately Well Sorted, WS $=$ Well sorted. 
Table 7: Modal composition of the Budhi Gandaki-Narayani Nadi sand

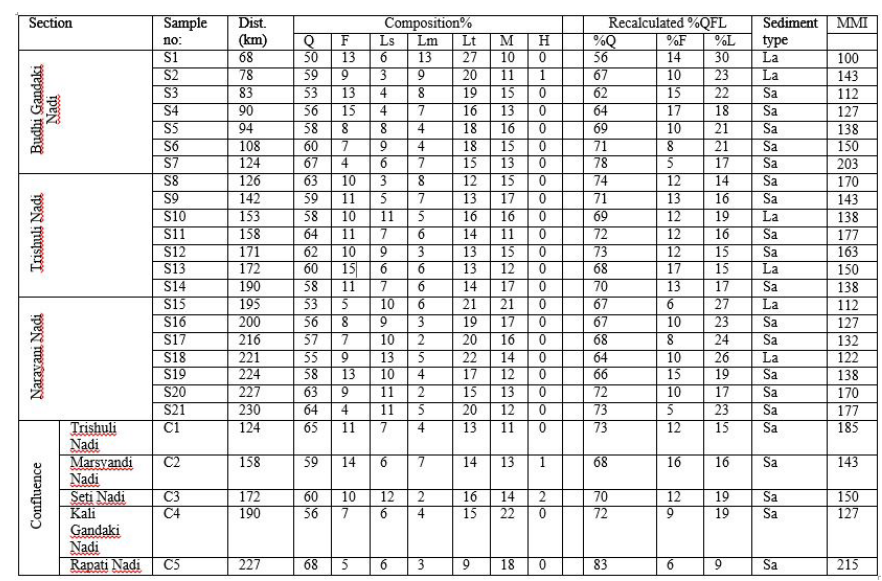

$\mathrm{Q}=$ quartz, $\mathrm{M}=$ mica, $\mathrm{F}=$ feldspar, $\mathrm{Ls}=$ total sedimentary rock fragment, $\mathrm{Lm}=$ total metamorphic rock fragments, $\mathrm{Lt}=$ total rock fragment, $\mathrm{H}=$ heavy minerals, $\mathrm{MMI}=$ modified maturity index, $\mathrm{Sa}=$ Sublitharenite and $\mathrm{La}=$ Lithic arenite
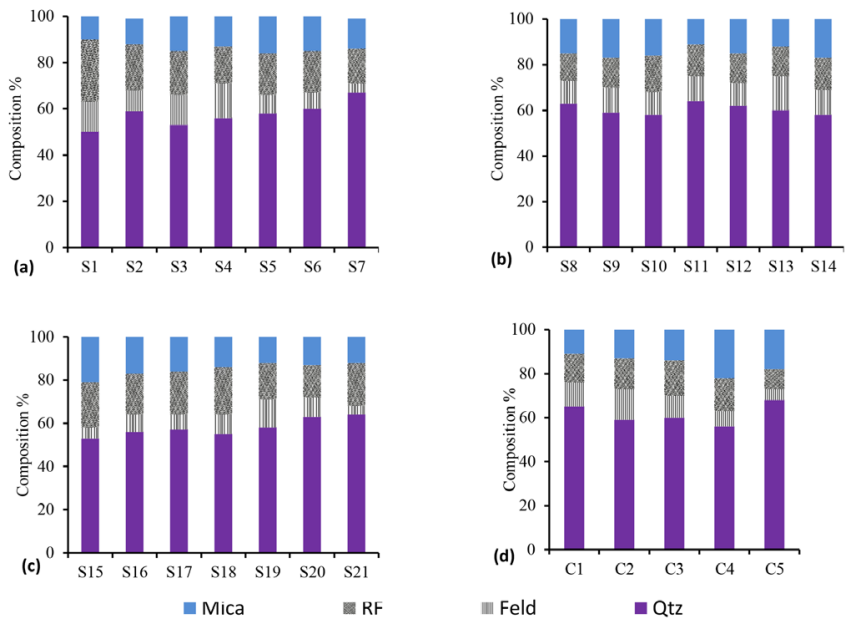

Fig. 8 (a) composition \% of the Budhi Gandaki Nadi, (b) composition $\%$ of the Trishuli Nadi, (c) composition \% of the Narayani Nadi and (d) composition $\%$ of confluence Rivers. Where, $\mathrm{RF}=$ Rock fragments, Mica $=$ muscovite, Feld $=$ feldspar, $\mathrm{Qtz}=$ quartz.

\section{Feldspar}

The percentage of feldspar decreases along the downstream distance. In the Budhi Gandaki Nadi Segment (from 68 to 124 $\mathrm{km}$ stretch), the feldspar ranges from $4 \%$ (S7) to $15 \%$ (S4). In the Trishuli Nadi Segment (126 to $190 \mathrm{~km}$ stretch), the feldspar ranges from $10 \%$ (S8) to $15 \%$ (S13). Similarly, in the Narayani Nadi Segment (195 to $230 \mathrm{~km}$ stretch), the feldspar ranges from 4\% (S21) to 13\% (S19) (Table 8; Fig. 8b). The trend line shows the diminishing trend of feldspar with the downstream distance of transport (Fig. 9b).

\section{Rock fragments}

The percentage of rock fragment varies in overall between 5\% and $27 \%$. Along the downstream distance of transport, rock fragments tend to diminish upto the end of the Trishuli Nadi Segment and again increases in the Narayani Nadi Segment, most probably due to tremendous mixing by the Kali Gandaki Nadi (Table 7, Fig. 9c).
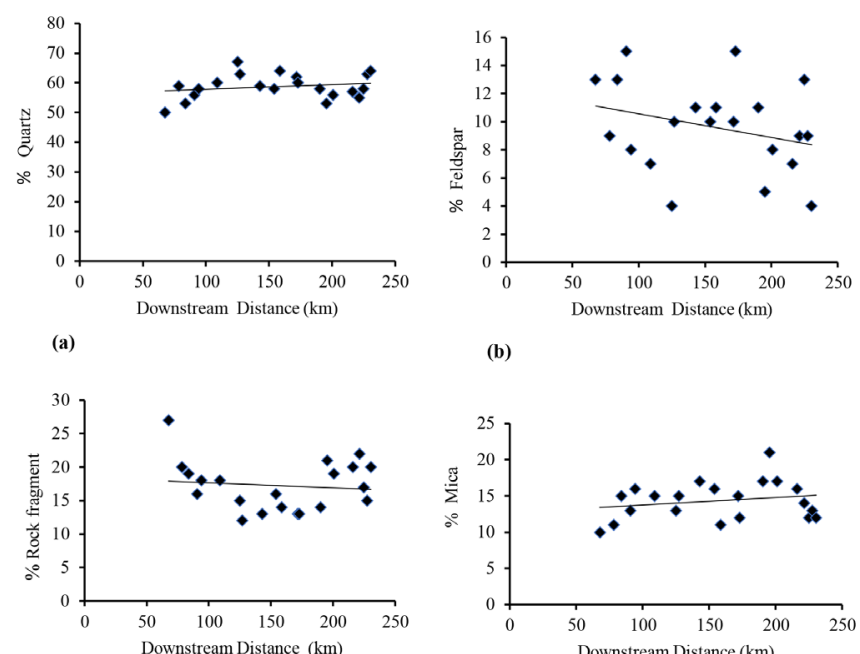

(b)

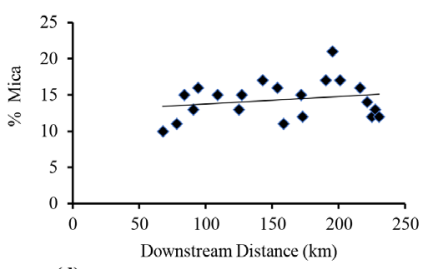

(d)

Fig. 9: Downstream changes of percentage of mineral grains of fluvial sand: (a) quartz, (b) feldspar, (c) rock fragments, and (d) mica

\section{Mica}

The mica content ranges from 10 (S1) to $16 \%$ (S5), 11 (S11) to $17 \%$ (S14), and 12 (S19 and S21) to 21\% (S15), respectively in the Budhi Gandaki Nadi, the Trishuli Nadi and the Narayani Nadi Segment (Table 7). The percentage of mica tends to increase along the downstream distance (Fig. 9d).

\section{Classification}

The bulk sands from the Budhi Gandaki Nadi, the Trishuli Nadi and the Narayani nadi are classified as sublithic and lithic in composition (Fig 10). The mineralogy of sands from the confluence rivers shows sublithic composition that means they are slightly quartzose compared to the main stem river, Budhi Gandaki-Narayani Nadi (Fig. 10).

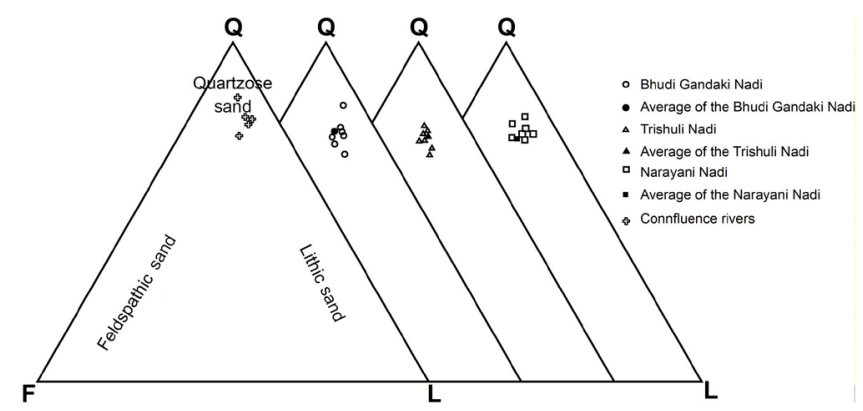

Fig. 10: QFL plot of fluvial sand of the Budhi Gandaki-Narayani Nadi.

\section{Modified Maturity Index (MMI)}

The MMI ranges from 100 to $203 \%, 138$ to $177 \%$ and 112 
to $177 \%$, respectively for sands from the Budhi Gandaki Nadi, the Trishuli Nadi and the Narayani Nadi segments. The maximum MMI (203\%) lies at $124 \mathrm{~km}$ downstream along the Budhi Gandaki Nadi Segment, whereas the least MMI (100\%) lies at $68 \mathrm{~km}$ downstream along the Budhi Gandaki Nadi Segment (Fig 11). As MMI for mature sand lies around $300 \%$, the Modified Maturity Index of the studied sands being less than $200 \%$ indicating that the studied sands from the Himalayan river have not achieved maturity yet.

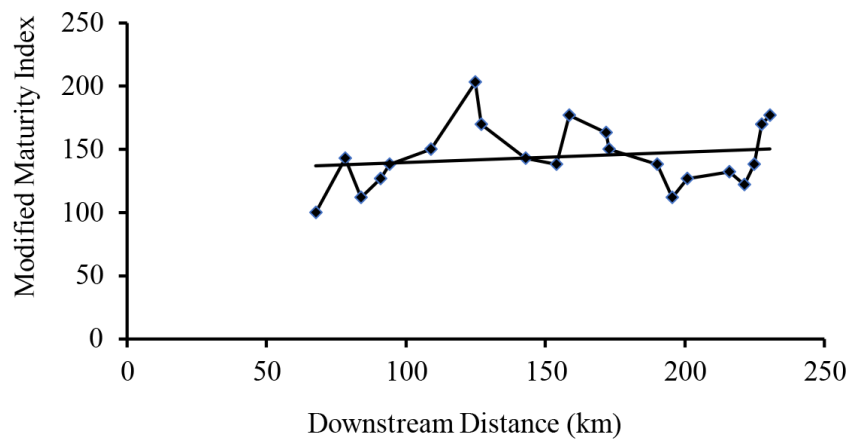

Fig. 11: Modified maturity index versus downstream distance along the Budhi Gandaki-Narayani Nadi

\section{Provenance study of the Budhi Gandaki-Narayani Nadi}

The provenance of the Budhi Gandaki-Narayani Nadi sands lies in recycle orogeny due to enriched quartz content and lithic fragments. The overall QFL composition of the Budhi Gandaki Nadi sands (S1 to S7) is Q67 F11 L22. The overall QFL composition of the Trishuli Nadi sands (S8 to S14) is Q71 F13 L16 and the overall QFL composition of the Narayani Nadi sands (S15 to S21) is Q68 F9 L23. The overall composition is sublithic sand in which the percent of quartz exceeds percent lithic fragments and feldspars. The sand samples plot on recycled orogeny field of the QFL, in agreement with the present-day environmental setting, where collision tectonics and subsequence folding and thrusting provide enormous sediments to the river (Fig. 12).
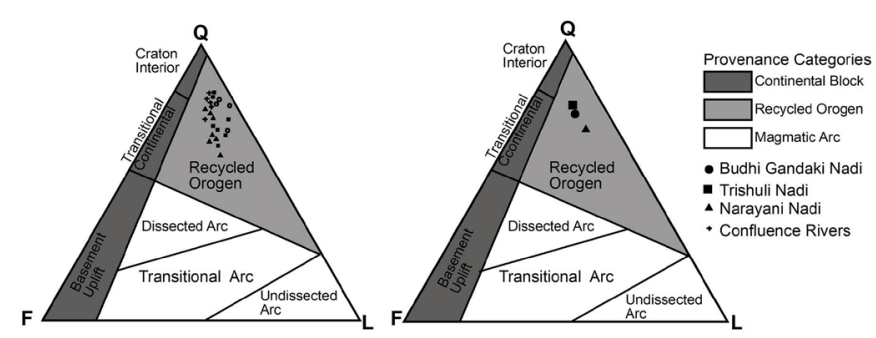

Fig. 12 (a) Ternary diagrams showing modal composition of the Budhi Gandaki-Narayani Nadi sand, and (b) Ternary diagram showing overall average modal composition of the Budhi Gandaki Nadi (S1 to S7), the Trishuli Nadi (S8 to S14) and the Narayani Nadi (S15 to S21)

\section{CONCLUSIONS}

1. This research focuses on sediment textural and compositional variation along the Budhi Gandaki-Narayani
Nadi. At the Budhi Gandaki-Narayani Nadi, sediments ranged from gravelly-sand to fine-grained sands. The sands from the confluence rivers such as C1 (Trishuli Nadi), C2 (Marsyandi Nadi), C3 (Seti Nadi), C4 (Kali Gandaki Nadi), and C5 (Rapati Nadi) show sand sediments.

2. Mean and median grain sizes of sand decreases from the Budhi Gandaki Nadi to the Narayani Nadi. Sorting improves along the river course than other statistical parameters. The skewness changes from coarse skewed to fine skewed from the Budhi Gandaki Nadi to Narayani Nadi showing the enrichment of fines in the lower reach. The kurtosis ranged from very platykurtic to leptokurtic. Fine skewed sands sort out better with the increased downstream distance of transport. The confluence rivers help bringing the fine materials as the fining of sand increase with increase of the downstream distance of transport.

3. Quartz grains, which are angular to sub angular, were derived from crystalline and high-grade metamorphic rocks. Tendency of increase in quartz roundness in the downstream stretches of the Budhi Gandaki-Narayani Nadi suggests abrasion of quartz grains, which were probably derived from the Higher Himalaya. As river emerges from the Tethys Himalaya to the Lesser Himalaya, the amount of feldspar diminishes due to its dilution by weathering and rapid breakdown. The textural and compositional maturities of sand improve downstream significantly.

4. The sands from the Budhi Gandaki-Narayani Nadi plot on recycled orogeny field of QFL diagram, and this result agrees with the current tectonic setup where sands have been originated and deposited in the tectonic set up of collision and recycled orogeny (Fig. 13).

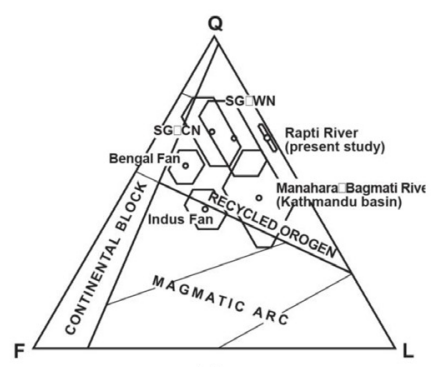

(a)

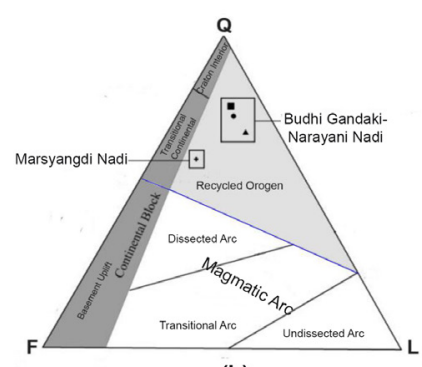

(b)
Fig. 13: Ternary diagrams: (a) QFL triangle showing provenance of sands from the Rapati River (Tamrakar et al. 2008), and comparison with sand and sandstones form other area like Manahara-Bagmati River of the Kathmandu Basin (Tamrakar and Gurmaita 2001), remnant-ocean sand of the modern Bengal and Indus Fans (from Ingersoll and Suczek 1979, and Suczek and Ingersoll 1985), foreland sandstone of the middle Miocene-Pliovene Siwalik Group of Central Nepal (SG-CN) (Tamrakar, 2004) and Siwalik Group of Western Nepal (SG-MWN) (Tamrakar 1993) (b) overall modal composition of the Budhi Gandaki-Narayani Nadis sand. Compositional field names and boundaries in diagrams are form Dickinson et al. (1983) and composition of Marsyandi sands, bulk petrography (Garzanti et al. 2007). 
5. The sands have been deposited by the graded suspension in highly turbulent flows in the Budhi Gandaki Nadi, and by the tractive current in the Narayani Nadi Segment indicating that those sands which have been currently transported and deposited by rivers, secures the mechanisms of both tractive transport and turbulent suspension transport in the C-M diagram.

6. The textural maturity of the Budhi Gandaki-Narayani Nadi has been verified as submature indicating that those sands from the rivers have not yet achieved maturity, presumably due to proximity of the source and due to active fluvial transport in high relief area.

7. The composition of the overall samples is sublithic sand in which the percent of quartz exceeds percent lithic fragments and feldspar. No distinct trends of variation could be observed for composition along the downstream distance of transport. The Modified Maturity Index MMI) ranges from 100 to $203 \%$, which is generally lower compared to the mature sand. Therefore, the compositional maturity of the sand is also poor as the textural maturity. The MMI also fluctuates along the downstream distance of transport, probably due to mixing by major rivers.

\section{REFERENCES}

Blair, T.C., and McPherson, J.G., 1999. Grain-size and textural classification of coarse sedimentary particles. J. Sed. Res. v. 69(1), pp. 6-19.

Colchen M., Fort, L.P., and Pecher, A., 1986. AnnapurnaManaslu-Ganesh Himal. Centre National de la Recherches Scientifique. Special Publication, Paris, pp. 136 (a geological map, 1:200 000 scale)

Curray, J.R., and Griffiths, J. C., 1995. Sphericity and Roundness of Quartz Grains in Sediments. Bulletin of the Geological Society of America, v. 66, pp. 1075-1096.

Dickinson, W.R., Lawton, T.F., and Inman, K.F., 1986. Sandstone detrital modes, central Utah Foreland region: Stratigraphic record of Cretaceous-Paleogene tectonic evolution. Jour. Sediment. Petrol., v. 56(2), pp. 276-293.

Dott, R.H., 1964. Wacke, graywacke and matrix-what approach to immature sandstone classification, J. Sed. Petrol. v. 34, pp. 625-632.

Folk, R.L., 1955. Student operator error in determination of roundness, sphericity, and grain size. Jour. Sediment. Petrol., v. 25, pp. 297-301.

Folk, R.L., 1966. A review of grain-size parameters. Sedimentology., v.6, pp. 73-93.

Folk, R.L., 1980. Petrology of sedimentary rock. Austin, Texas, Hemphill, 182 p.

Folk, R.L., and Ward, W. C., 1957. Brazos river bars, a study in the significance of grain size parameters. Jour. Sed. Petrol., v. 27 , pp. 3-26.
Garzanti, E., Vezzoli, G., Ando, S. Lave, J. Attol, M. Lanord, C.F, and DeCelles, P., 2007. Quantifying Sand provenance and erosion (Marsyandi River, Nepal Himalaya). Journal of Earth and Planetary Science Letters, 258, pp. 500-515.

Garzanti, E., Vermeesch, P., Andò, S., Lustrino, M., Padoan, M., and Vezzoli, G., 2014. Ultra-long distance littoral transport of Orange sand provenance of the Skeleton Coast Erg (Namibia). Journal of Marine Geology.

Hulka, C., and Heubeck, C., 2010, Eastward Andean growth recorded by sandstone petrology and provenance of the Chaco foreland basin fill, southern Bolivia: Journal of Sedimentary Research, 80, p. 288-299, DOI: 10.2110/jsr.2010.029.

Ingersoll, R.V. Bullard, T.F., Ford, R.L., Grimm, J.P., Pickle. J.D., and Sares, S.W., 1984, The dffect of grain size on detrital modes: A test of the Gazzi-Dickinson Point-counting method. Jour. Sediment. Petrol., v. 54(1), pp.103-116.

McBride, E.F., and Picard, M. D., 1987. Downstream changes in sand composition, roundness, and gravel size in a shortheaded, high-gradient stream, Northwestern Italy. Jour. Sediment. Petrol., v. 57(6), pp. 1018-1026.

Powers, M.C., 1953. A new roundness scale for sedimentary particles. Jour. Sediment. Petrol., v. 23, pp. 117-136.

Rittenhouse, G., 1943. A visual method of estimating twodimensional sphericity. Jour. Sed. Petrol., v. 13(1), pp. 79-81.

Tamrakar, N.K., Maharjan, S., and Shrestha, M.B., 2008. Petrology of Rapati River sand, Hetauda-Chitwan Dun Basin, Central Nepal; an example of recycled provenance. Bulletin of the Department of Geology, Tribhuvan University, Kathmandu, Nepal, v.11, 2008, pp. 23-30.

Tamrakar, N.K., and Shrestha, M.B., 2008. Relationship between fluvial clastic sediment and source rock abundance in Rapati River Basin of Central Nepal Himalaya. Boletin de Geologia, v. 30(1), pp. 63-75.

Tamrakar, N.K., 2009. Riverbed-material texture and composition of Bishnumati River, Kathmandu, Nepal; implication in provenance analysis. Bulletin of the Dept. of Geology, Tribhuvan University, Kathmandu, Nepal, v. 12, 2009, pp. 55-62.

Wentworth, C.K., 1922. A scale of grade and class terms for clastic sediments. J. Geol. v. 30, pp. 377-392. 